\title{
Jesus-oriented visions of Judaism in antiquity
}

\author{
KARIN HEDNER ZETTERHOLM
}

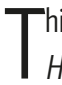
his article argues that the Pseudo-Clementine Recognitions 1.27-72, the Pseudo-Clementine Homilies, and the Didascalia Apostolorum - third and fourth century-texts, which combine adherence to Jesus with Jewish law observance - would have made sense to Jews in antiquity as Jewish, although non-rabbinic visions of the history and calling of the people of Israel, and that they ought to be considered as part of the history of Judaism. Recent years have witnessed an emerging trend to reread texts previously regarded as 'Jewish-Christian' or 'heretical Christian' as Jewish texts, and as evidence of diversity within Judaism in the post-70 period. This understanding emerges from the related insights that rabbinic Judaism was not the only, or even the dominant

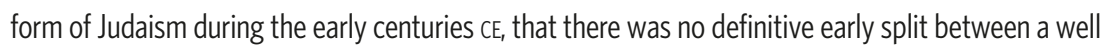
defined Christianity and an equally well defined Judaism, and that Jewish self-identity in antiquity seems to have allowed for adherence to Jesus as an option within Judaism. Abandoning the practice of using rabbinic Judaism as the sole criterion for defining Jewishness in this time period allows us to see the theologies developed by such Jesus-oriented groups with a Jewish self-identity as profoundly Jewish, although non-rabbinic, visions of the history and calling of biblical Israel.
\end{abstract}

The main argument of this article is that the Pseudo-Clementine Recognitions 1.27-72, the Pseudo-Clementine Homilies, and the Didascalia Apostolorum - third- and fourth-century texts, which combine adherence to Jesus with Jewish law observance - would have made sense to Jews in antiquity as Jewish, although non-rabbinic visions of the history and calling of the people of Israel, and that they ought to be considered as part of the history of Judaism. Traditionally seen as 'Jewish-Christian', that is to say, as expressions of a nonorthodox, heretical Christianity, the place of these texts within the history of Judaism has only recently begun to be explored in light of the scholarly insight that Jesus-orientation was not the clear demarcation line between Jews and 'Christians' that it was previously made out to be, but rather an option within Judaism for several centuries (Boyarin 2012, Frankfurter 2007). We are used to seeing Judaism and Christianity as two mutually exclusive categories, but this was not necessarily the case in antiquity. People seem to have combined 
adherence to Jesus with Jewish practices for several centuries, at least in some locations (Kimelman i 999).

In addition to claims already made as to the Jewish nature of these texts (see Fonrobert 200I; Jones I995; Marcus 2010; Reed 2007, 2008), ${ }^{1}$ I argue that their theologies as a whole, not just particular traditions, ideas or interpretive practices, would have made sense to Jews in antiquity as coherent Jewish visions of the history and calling of the people of Israel, provided we allow for expressions of Judaism other than the rabbinic one. First, I will provide a brief outline of each of the texts, focusing on their views of Jesus, baptism, and the inclusion of Gentiles in the covenant with Israel's God, and then attempt to show that during the fourth century these features, commonly associated with Christianity, may still have been perceived as being part of Judaism. Recognitions I.27-7I is the shortest text, which is why it takes up less space here than the other two.

In order to not automatically exclude the possibility that the authors/redactors of these texts and their communities may have had a Jewish self-identity while at the same time embracing Jesus, I refer to them as 'Jesus-oriented' rather than 'Christian'. Even in cases where a text itself uses the term 'Christian' we must keep in mind that the author may simply be using it in the sense of 'Jesusoriented', without the connotation of 'non-Jewish' that the term 'Christian' would later have. For the same reason, I will translate the Syriac ' $d t$ ' and the Latin ecclesia literally as 'assembly' rather than 'church' as opposed to most translations. Depending on the text and context, m'mwdyt'/baptisma refers either to a one-time initiation rite, in which case I translate it as 'baptism', or to regular ablutions, either for the remission of sins or purification from bodily defilement, in which cases I translate it as 'immersion'.

\section{The Pseudo-Clementine Recognitions 1.27-71}

According to F. Stanley Jones (I995: I63-67), Recognitions I.27-7 I was composed c. $200 \mathrm{CE}$ by a 'Jewish Christian', probably in the area of Judaea. Apart from small fragments of Greek, larger portions of Recognitions I.27-7 I are preserved only in a Latin (Rehm I 965) and a Syriac (Frankenberg I 937) version. ${ }^{2}$ The author(s)/redactor(s) (henceforth author) represents a Judaism that sees

F. Stanley Jones, however, continues to regard Recognitions I.27-7I as a Christian text, contrasting it with Jewish tradition, see Jones (2012) pp. 267-8, 275.

2 Translations are taken from Jones 1995 but are occasionally modified upon consultation with the original. 
Jesus as the Messiah, and for which adherence to Jesus is true Judaism (Jones I995: I60). Features adduced by scholars as indicating that the author was a Jesus-believing Jew include concern with the land of Israel, praise of Hebrew as the original language of humankind, depiction of Jesus-adherents as an innerJewish movement, interest in Jews who secretly believe in Jesus, and a generally sympathetic portrait of non-Jesus-oriented Jews (ibid. I 57-68; Reed 2007: 204-13).

Jesus; a prophet like Moses

Recognitions I.27-7I is a retelling of Israel's history from the creation to Jesus, who is seen as a second Moses and the future prophet promised by God through Moses; 'The Lord your God will raise up for you a prophet like me. Listen to him in all matters' (I.36.2). The identification of Jesus with the future prophet promised by God in Deut. I 8:15-18, in whose mouth he will put his words, gives him unparalleled authority in the eyes of the author of Recognitions I. $27-7$ I.

Completing the work of Moses, Jesus institutes immersion in the place of sacrifices for the forgiveness of sins, '[i]n order that they do not think that they were being deprived of the forgiveness of sins that accrued through sacrifices ... immersion in water [ $\mathrm{m}^{\prime} m w d y t^{\prime} /$ baptisma] for the forgiveness of sins was instituted' (I.39.2). The commandment to sacrifice was instituted by Moses as a means of keeping the Israelites from worshipping foreign gods (I.36.I), but it was to be in force only until the coming of the future prophet promised by God, who would make the Israelites 'understand that God desires kindness, not sacrifices' (I.37.I) (Syriac).

Like Moses, Jesus performs signs and miracles (I.4I.I-2; I.57.5; I.58.2-3), but as both prophet and Messiah, he is greater than Moses (I.59.2-3). In a statement placed in the mouth of the apostle Peter the author asserts that, "it is impossible to know the things that are pleasing to God without the prophet of truth' (I.44.5), and that recognition that Jesus is the Messiah is a necessary condition for salvation (1.63.2) (Reed 2007: 213).

However, non-Jesus-oriented Jews are not blamed for their failure to accept Jesus. This state of affairs is explained as being part of the divine plan as announced by the prophets ( $1.50: 2-5$ ), or as the result of the numerous schisms among the people (I.54.8), and to the interference of Paul, who just as James had succeeded in persuading 'the whole people and the chief priests' (Latin r.69.8) that Jesus was the Messiah, instigated a great commotion among the people, ending with the death of James (1.69.8-70.7). 
Jews and Jesus-oriented Gentiles

The author's focus is on the Jews, Jesus-oriented and otherwise, and although he believes that Gentiles may be included in the covenant with Israel's God this is only because they get to fill the slots left empty by those Jews who have not embraced Jesus (I.42.I). The calling of the Gentiles is described as 'necessary' (Latin) and is said to have resulted in 'confusion' (Syriac) (I.42.I), terms, which seem to indicate the author's lack of enthusiasm for the mission to the Gentiles.

Statements to the effect that adherence to Jesus is the only difference between 'us and those among our people who do not believe' (I.43.2) suggest that the community was Torah observant and that they believed that the only laws abolished by Jesus were the laws of sacrifices, laws which would not have been practised by non-Jesus-oriented Jews either. This is also indicated by the author's assertion that God at the end of time 'will please those who have kept and performed the law' (I.5 I.4). Unfortunately, the text reveals nothing about the author's view of law observance among the Gentile Jesus-adherents. He may have thought, with the Jesus-believing Pharisees in Acts I 5:5 (and possibly the author of the Gospel of Matthew), that they must be circumcised and obligated to observe the Torah like Jews, or he may have believed they should remain Gentiles and keep some Torah commandments. We simply do not know, but of interest in this context is Jones's tentative claim that Recognitions I.27-7 I was originally composed under the name of Matthew (Jones I 995: I 55).

In sum: Jesus is seen as a Messianic prophet, a second Moses who has come to complete the work of Moses, abolishing sacrifice and instituting in its place immersion in water for the forgiveness of sins. He represents a new stage in the history of the people of Israel and the fulfillment of God's promises to them. The author could perhaps be said to embrace a 'remnant theology' but without condemning those Jews who do not accept Jesus as the Messiah. In this messianic age, Gentiles may be included in the covenant with Israel's God, but only by filling the slots left empty by non-Jesus-believing Jews.

\section{The Pseudo-Clementine Homilies}

The Homilies is the older of the two main works included in the PseudoClementine writings, which relate a fictitious tale of the life of Clement of Rome and his travels with the apostle Peter. It is commonly believed to have originated in Syria and was redacted in the early fourth century, but is a reworking of an earlier, no longer extant, source dating from the early third century. The original Greek of the Homilies is preserved (Rehm I 953) as well as a Syriac 
translation of chapters IO-I 4, extant in a manuscript written in Edessa in $4 \mathrm{II}_{\mathrm{I}}{ }^{3}$ The other main work of the Pseudo-Clementine writings is the Recognitions, a slightly later reworking of the same early third-century source. The Recognitions survives in full only in a Latin translation from $c$. 406. There are also later epitomes of the Homilies and/or the Recognitions in Greek, Arabic, Georgian, and Armenian suggesting a rather widespread circulation (Brenner 2010: I-I2; Jones 20I 2: 3-I6).

The Homilies is mainly concerned with the spreading of the message of the one God to the Gentiles (Hom. 3.59), with Clement, a former 'pagan' who through the teachings of Peter embraces belief in the one God and in 'the doctrine of the Prophet' (Hom. 2.4) as one of the main protagonists. A focus on Gentiles, although often taken by scholars as an indication of non-Jewish authorship, fits well within a Jewish theological construction of Israel as a light to the nations of the world. The Jewish outlook of the Homilies is further indicated by the authors'/redactors' (henceforth author) division of the world into Jews and Gentiles/Peoples/Nations (ethnē) and his view of the latter as idolaters and subject to the power of demons. Citing the author's emphasis on the importance of Moses, the Torah, halakhic observance, and assertions of the continued 'chosenness' of the Jews as indications of a Jewish self-identity, Annette Yoshiko Reed has persuasively argued that the Homilies in its redacted form represents a Jewish identity that included adherence to Jesus (Reed 2007: 2 I 3-24; Reed 2008: I 82-96; Reed 201 3: 885-9 I). Below I will attempt to show how his focus on Gentiles, his view of Jesus, and immersion for the remission of sins (baptism) would have made sense within a Jewish worldview.

\section{Baptism and the inclusion of Gentiles}

Unlike Recognitions I:27-7 I, the Homilies' main concern is the Gentiles and their inclusion in the covenant with the God of the Jews. 'Polluted in body and soul', and ignorant of the law and through evil deeds, they are utterly lost and subject to the power of demons and Satan (8.22). However, if they abandon idolatry, turn to the one God and take it upon themselves to observe a limited number of Torah commandments, they can be granted privileges that the Jews have long enjoyed. Addressing Gentiles Peter says:

3 Translations are adapted from Roberts and Donaldson (I 870) with modifications upon consultation with the original. 


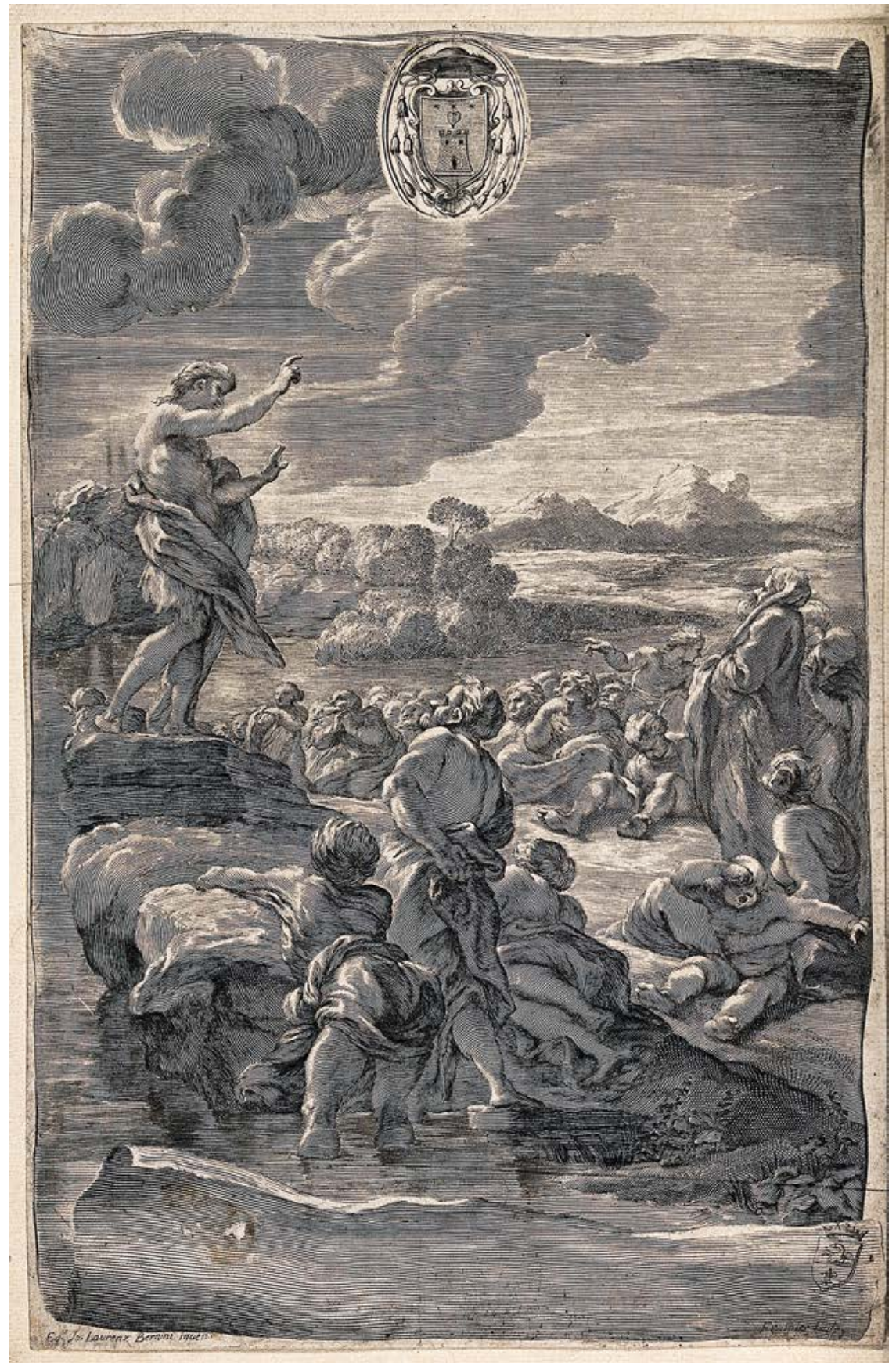

John the Baptist preaching to a multitude at the river Jordan.

Engraving by F. Spierre after G. L. Bernini. Wellcome Images. 
Choosing, therefore, to worship one God, and refraining from the table of demons, and undertaking chastity with philanthropy and righteousness, and being immersed with the thrice-blessed invocation for the remission of sins, and devoting yourselves as much as you can to the perfection of purity, you can escape everlasting punishment, and be constituted heirs of eternal blessings. (9.23)

Through immersion, perceived as an initiation rite 'with the thrice-blessed invocation' for the remission of sins and through observance of the Law they may be saved from 'superstition with respect to idols, and wickedness, which reigns over them' (2.33). Through worship of the one God and immersion Gentiles are able to drive away evil spirits and demons and become more like (law-observant) Jews, over whom demons have no power (9.19-20).

Immersion for the remission of sins was practised by the Qumran community (IQS 3,4-9), and according to Josephus and the synoptic gospels, also by other first-century Jews. John the Baptist is described as a preacher of repentance proclaiming 'a baptism of repentance for the forgiveness of sins' (Mark I:4; Ant. I 8. I I 7), and is said to have immersed people in the Jordan River, 'And people from the whole of Judean countryside and all the people of Jerusalem were going out to him, and were baptized by him in the river Jordan, confessing their sins' (Mark I:5; cf. Matt. 3:5; Luke 3:3).

When practised by Gentiles wishing to join a Jesus-oriented community, however, it seems to have had a slightly different significance. While John immersed individual Jews who wished to repent, immersion of Gentiles as an initiation rite (baptism) in the Homilies seems above all to signify a switch of categories. The Gentile leaves the category of 'Gentiles', and being cleansed of the sinful nature of Gentiles as Gentiles, the person becomes potentially able to observe the commandments of the Torah and obtains a status equal to that of Jews. Provided the 'convert' now keeps the commandments that apply to him/ her, he/she can escape 'everlasting punishment' and 'become heirs of eternal blessings'. Both Jews and Jesus-oriented Gentiles are judged on the basis of their actions, but while Jews are born into the covenant with Israel's God, Jesusbelieving Gentiles are included through baptism, a ceremony by which they are cleansed of their old sinful nature and become potentially salvable.

Jesus-oriented Gentiles do not seem to become Jews however, and for them belief in the God of Israel and Jesus, the prophet of truth, is perceived as a kind of Judaism for non-Jews. In general, the author of the Homilies prefers the term theosebeia ('fear of God') rather than 'Judaism' as the designation of the way of 
life its protagonists practise and teach (2.I; I $2 . \mathrm{II}),{ }^{4}$ a term that by the third century may have been appropriated by groups of Jews as a self-designation. They preferred theosebeia over the more general eusebeia used by 'pagans' to denote piety - probably because it points more directly to Jewish worship of the one God and rejection of idolatry - and the term often seems to refer to Jews (Lieu I 995: 493-7). 5 In one passage our author seems to use 'God-fearer' and 'Jew' as synonyms:

For he is a God-fearer [theosebees], of whom I speak, who is truly Godfearing [ theosebes], not one who is such only in name, but who really practices the Law that has been given him. If any one acts impiously, he is not pious; in like manners, if he who is of another tribe keeps the Law, he is a Jew; but he who does not keep it is a Greek. For the Jew trusts God and keeps the Law.... But he who keeps not the Law is manifestly a deserter through not trusting God; and thus as no Jew, but a sinner, he is on account of his sin brought into subjection to those sufferings which are ordained for the punishments of sinners. (Hom. I I.I6.2-4)

According to this passage a Jesus-believing, law-observant Gentile is a Jew, which - considering the emphasis on law observance here - probably means that he is like a Jew. This is not a 'halakhic' redefinition of who is a Jew, but rather an argument about the importance of living in accordance with the Law, where 'Jew' stands for an ideal, Torah-observant Jew. A Jesus-believing Gentile who keeps the Law is a Jew, meaning that he or she behaves 'jewishly', whereas the non-law-observant, Jesus-believing Gentile reverts to the status of a 'pagan' Greek. It is noteworthy that a Jew who is not Torah-observant, that is a Jew who does not behave 'jewishly' is not called a Greek, but a sinner. ${ }^{6}$

4 The term theosebess ('God-fearer') is often used as a designation for Gentiles who affiliate themselves with Judaism without undergoing conversion, but it can also be used to denote any pious person, Gentile or Jew; see the discussion in Reynolds and Tannenbaum (1987). However, most of the evidence discussed dates from the first and second centuries with only a few examples from later centuries.

5 See also Jones (201 2: I 5O-I), who discusses theosebeia and theosebees as self-designations for the author of the early third-century source of the Homilies.

6 See Nanos (2014: 26-32), who discusses the importance of distinguishing between the ethnic identity of Jews and behaviour that characterizes Jews (behaving 'jewishly') when reading Paul. Paul makes a point similar to the one above in Rom. 2:1 $7^{-29}$, see ibid. 39-5 I. 
The requirements for Gentiles who want to join a Jesus community are summarized in the following way:

And this is the service He has appointed: To worship Him only, and trust only in the Prophet of truth, and to be immersed for the remission of sins, and thus by this pure immersion to be born again unto God by saving water; to abstain from the table of devils, that is, from food offered to idols, from dead carcasses, from animals which have been suffocated or caught by wild beasts, and from blood; not to live any longer impurely; to wash after intercourse, that the women on their part should keep the law of purification; that all should be sober-minded, given to good works, refraining from wrong-doing, looking for eternal life from the all powerful God, and asking with prayer and continual supplication that they may win it. (7.8)

In addition to the laws prescribed by the Decree of the Apostles (Acts I 5:20), the author of the Homilies also wants Gentiles to observe some Jewish food and purity laws in order to have a place in the Jesus movement. ${ }^{7}$

Jesus the prophet of truth

Jesus and Moses are seen as two earthly manifestations of the Prophet of truth (2.15-16), sent by God to teach the same truth to two different peoples, Moses to the Jews and Jesus to the Gentiles: 'Since, therefore, both to the Hebrews and for those who are called from the Nations, believing in the teachers of truth is of God' (Hom. 8.5).

Although the ideal is to believe in both Moses and Jesus, the Jews who do not accept Jesus as the Messiah are not at fault. This is all part of the divine plan, according to which God has chosen to conceal him from them in order that he may be known among the Gentiles, 'For on this account Jesus is concealed from the Hebrews who have taken Moses as their teacher, and Moses is hidden from those who have believed Jesus. For, there being one teaching by both, God accepts him who has believed either of these' (8.6). The Homilies represents an 'addition theology', according to which Jesus-oriented Gentiles are added to the original people of God, but not at the expense of non-Jesus-oriented Jews

7 Thus, like the rabbis the authors/redactors of the Homilies attribute ritual impurity to Gentiles, see Reed 2013: 891. For ritual laws incumbent upon Gentiles in the Homilies, see Zellentin 2013: 94-I 25. 
who remain in the covenant even though they have not embraced Jesus as the Messiah.

The author of the Homilies has a special interest in prophecy, which is considered the only reliable knowledge about God. Jesus, the prophet of truth, is the last in a line of a series of prophets, including Adam and Moses (2.15-16; 3:I $7-2$ I) and he is the only source of true knowledge about God: 'For apart from Him ... it is impossible to learn the truth' $(2: 4)$.

Hence, $\mathrm{O}$ beloved Clement, if you would know the things pertaining to God, you have to learn them from Him alone, because He alone knows the truth. For if any one else knows anything, he has received it from Him or from His disciples. (2.I 2 , cf. $2.5^{-6}$; 3 . I I)

As the only reliable source of knowledge about God and the prophet of truth, Jesus' teachings are the guide to a correct understanding of Scripture. Jesus as the prophet of truth has supreme authority to interpret the Law and proof of his ultimate authority is his identification with the prophet proclaimed by Moses in Deut. I 8:1 5-i 9:

But also a witnessing voice was heard from heaven, saying, 'This is my beloved Son, in whom I am well pleased; hear Him' [Matt. I 7:5] ... Still further He [Jesus] said, 'I am he concerning whom Moses prophesized, saying, "The Lord our God will raise up for you from your own people a prophet like me. You must listen to whatever he tells you." And everyone who does not listen to that prophet will be rooted out of the people' [Acts 3:22-23 citing Deut. I 8: I5]. (3.53)

The teachings of this prophet promised by God through Moses must be followed (2.I I). They are transmitted via Peter, who by virtue of being the apostle of the prophet of truth speaks the truth (7.I I; I7.I9), and transmission continues through James and the Jerusalem church (I I.35) to the bishops (3.6o-72). Proper succession vouchsafes the faithful transmission of the teachings of Jesus (Reed 2008: 186-7).

In spite of its insistence that Jesus is the only source of knowledge about God, the Homilies recognizes the continuance of proper succession among nonJesus-oriented Jews on the basis of Jesus' assertion that the Pharisees 'sit in the seat of Moses' and are entrusted with 'the key to the kingdom of heaven, which is knowledge' (Matt 23:2; Hom. 3.I 8, 47). Prophecy is the only means by which one can know God, but somewhat surprisingly rabbinic Jews - like adherents 


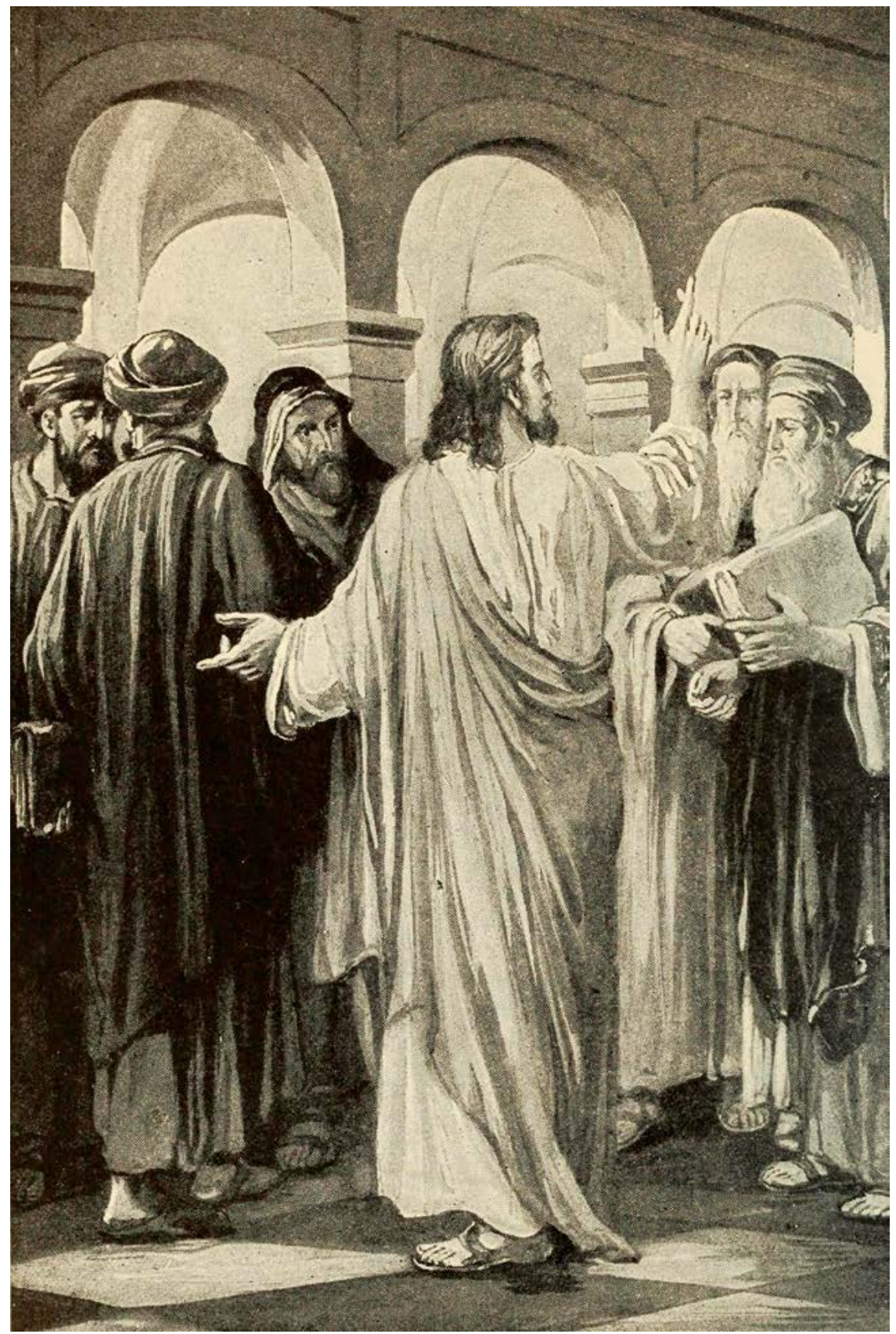

'Christ and the scribes' in Our day in the light of prophecy and providence by William Ambrose Spicer (Canadian Watchman Press, 1921). 
to Jesus - have access to prophetic truth by virtue of being heirs to Moses and the Pharisees. Accordingly, prophetic truth seems to be transmitted along parallel lines of prophetic succession, through the Pharisees in the 'seat of Moses' (3.I8) on the one hand, and through Peter's bishops in the 'seat of Christ' on the other (3.60) (Reed 2008: I9I-4; Reed 2013: 887-92). It is noteworthy that rabbinic Jews are considered to be in the possession of truth by virtue of their link to prophecy.

\section{The Didascalia Apostolorum}

The Didascalia Apostolorum purports to be teachings by Jesus' original apostles, but is a third-century community-rule text that seems to have undergone several redactions, of which the latest took place in the early fourth century, most likely in Syria. Originally written in Greek, it was translated into Latin, Syriac, Ethiopian, and Arabic, indicating a wide circulation (surveys in StewartSykes 2009: 3-55; Vööbus I 979: 23-33). I mostly cite from the Syriac edition (Vööbus I 979), since Syriac was likely the language in which the Jews of Syria and Mesopotamia encountered these ideas. ${ }^{8}$ Scholarly attempts to capture the combination of Jesus-centeredness and Jewish character of the text include defining the authors/redactors (henceforth author) as 'a Christian of Jewish birth' (Marcus 2010: 606), the text as a 'Mishnah for the disciples of Jesus' (Fonrobert 200I: 483), and as 'a Christian legal document with affinities to Judaism' (Zellentin 2013: viii-ix).

Although the author claims to be a Jew, calling himself a disciple 'from the House of Judah' ( $D A 26$ 407:248/408:230), this is often dismissed by scholars as being part of the literary fiction that attributes authorship to Jesus' original disciples (Stewart-Sykes 2009: 24n45). However, some scholars have argued that his extensive knowledge of Jewish traditions and practices beyond what is found in the Bible, and his use of 'rabbinic-like' hermeneutics indicate that the author was a Jew (Fonrobert 2001: 502-6; Marcus 2010: 606-7).

He calls the members of his community 'Christians', a fact that would seem to make the Didascalia difficult to claim for Judaism, but we should not automatically assume that 'Christian' here means non-Jewish. For us, 'Jewish' and 'Christian' are mutually exclusive categories, but the author of the Didascalia rather seems to use 'Christian' in the sense of a specific kind of Judaism - a the original. The Syriac text appears in vols. $40 \mathrm{O}$ and 407 , and the English translation in vols. 402 and 408 . 
subgroup within Judaism who believes that Jesus is the Messiah. He betrays a Jewish outlook in the way he addresses the two groups in his audience as 'us who were called from the people' and 'you, who were called from the peoples' ( $D A$ 26 407:25I/408:23I), and although such a Jewish division of the world into Jews, referred to as 'the People' (' $m$ ') and non-Jews, referred to as 'the Peoples/ Nations' can also be dismissed as part of the narrative framework, its consistency throughout the work is noteworthy. It seems to me that the insistence that the author is not Jewish prevalent in much earlier scholarship derives from the assumption that belief in Jesus is considered irreconcilable with a Jewish identity. Leaving the precise identity of the author aside, I wish to focus here on whether his theology would have made sense to fourth-century Jews as a coherent vision of the mission of the people of Israel.

Assuming that the author addresses a real community, it appears to have been made up of a mixture of Jesus-oriented Jews and Gentiles. He calls the Jews 'dear brothers' who 'trust in God our saviour Jesus the Messiah' but criticizes them for maintaining Jewish practices such as food and purity regulations and for giving priority to the Sabbath over Sunday $(D A 26)$. At the same time he repeatedly claims that Jesus has affirmed the Law, not abolished it, indicating that he has a different view on which commandments of the Torah that are binding than some members of his community. ${ }^{9}$

\section{Jesus as lawgiver}

The author/redactor of the Didascalia seems to perceive a straight line connecting the giving of the Torah at Sinai (Exod. 19-24) with the coming of Jesus whose main function is to restore the Torah (Syriac nmws') to its original state, as it was before the Israelites worshipped the golden calf (Exod. 32). According to the Didascalia's reading of the Book of Exodus, the Israelites were given two sets of laws at Sinai. The first set, consisting of 'the ten sayings' (Exod. I9-20) and 'the judgments' (Exod. 2 Iff.), is good and eternal, whereas the second set given after they worshipped the golden calf is temporary - detailed regulations

9 Zellentin (2013: 85-96) warns against automatically equating the Didascalia's construction of its audience with actual social-historical circumstances, but concludes that the 'Judaizing' group is described in such detail and addressed at such length that it seems to reflect actual practices rather than being a heresiological construct. However, noting that the issues under debate in the Didascalia correspond to the list of observances incumbent upon Gentiles in the Homilies, he suggests that the debate concerns Gentile Jesus-adherents and considers fictitious the author's attribution of these practices to Jewish Jesus-adherents. 
concerning sacrifices, dietary laws and purifications - and imposed in order to keep them from reverting to idolatry. Making a distinction within biblical law, he calls this second set 'the second law' (Syriac tnyn nmws' Greek deuterosis) and argues that these laws, as opposed to the 'first law' (nmws' qdmy'), are temporary and in force only until Jesus comes to abolish them:

Let this be before your eyes, that you know what in the Law [nmws'] is the Law and what are the bonds that are in the second law [tnyn nmws'], which after the Law, were given to those who, in the Law and in the second law, sinned in all those sins in the desert. For the first Law [nmws' qdmy'] is that which the Lord God spoke before the people made the calf and served idols, that is the ten sayings and the judgments. And after they have served idols, He rightly set upon them bonds, as they deserved, but do not therefore set them upon yourself for our Savior came for no other reason than to fulfill the Law and release us from the bonds of the second law ... ( $D A_{2}$ $\mathrm{CSCO}_{\left.40 \mathrm{I}: \mathrm{I} 8 / 402: \mathrm{I}_{5}\right)^{10}}$

The second law is said to have been imposed 'in the heat of his [God's] anger - yet with the mercy of his goodness' ( $D A 26408: 226$ ), which seems to indicate that it was not so much a punishment as a necessary means to make the Israelites focus their attention on Israel's God and preventing them from reverting to idolatry. That the worship of the golden calf is Israel's cardinal sin is a view he shares both with the rabbis and the author of Recognitions I-27-7 I (t. Shabb. I: 16; t. Meg. 3.36-7). Through Jesus, God has released his people from the second law, and in doing so he has affirmed the validity of the first law, also defined as the 'simple Law' (nmws' prsyt'), whose content and spirit agree with the prophets and the Gospel:

...[F] or our Savior came for no other reason than to fulfill the law and release us from the bonds of the second law ... Thus, he called those who put their trust in Him and said: 'Come to me, all who labor and are heavily burdened and I will give you rest' [Matt. I I:28]. Therefore, without the weight of these burdens, read the simple Law, which agrees with the Gospel; and again the Gospel itself, and the Prophets... (DA 2 40r: 8 I $9 / 402:$ : 5 )

10 The term deuterosis is used in fourth-century patristic sources to refer to extra-biblical teachings of the Jews, but the Didascalia's use is different, see the discussion in YadinIsrael 20I3: 92 I-6, 933-5. 
Those who insist on keeping the commandments of the second law after Jesus has restored the Law to its original state demonstrate their lack of trust in Jesus' power to release them from it, and by implication their lack of trust in the God who has sent him: 'Those, therefore, who do not obey him, that he may lighten and save them from the bonds of the second legislation, do not obey God, who has called them to come forth unto release and rest and relief...' ( $D A$ 27 408:230). Such lack of trust in God is what caused the Israelites' worship of the golden calf and accordingly observing the second law is the equivalent of idolatry: 'If you take upon you the second law, you are also taking up idolatry, the reason why the second law was imposed.... And do not load yourselves again with something which our Lord and Savior has taken away from you' (DA 26 408:242-3).

The idea that lack of trust in Jesus is the present-day equivalent of calfworship, explains why it is so important for the author that the members of his community refrain from practices that are based on the second law. Clearly, though, the rejection of the second law is not an attack on the Law itself, but an argument about its scope and correct interpretation. Jesus has come not 'to abrogate the Law, nor the Prophets, but to fulfill them' [Matt. 5:I7] ( $D A 26$ 407:242/408:224). He has the power to abolish the second law and reestablish the first, original Law that signifies the pre-calf covenant, and in doing so he becomes the hermeneutic key for the interpretation of the Torah.

\section{Baptism and the inclusion of Gentiles}

The Law given to the Israelites ('the first people') 11 before the golden calf episode now also applies to the Gentiles ('the peoples'). These two groups Jesus-oriented Jews and Jesus-oriented Gentiles - together make up 'the present assembly of God':

The Law is said to be a yoke because, like a yoke used for plowing, it is laid on the first people [' $m$ ' $q d m y$ '] and also upon the present assembly of God [' $d t^{\prime} d ' l w '$. And now it is upon us, upon those who were called from the People [' $m$ '] and upon you and on those who are from the Peoples/Nations [byt ' $m m^{\prime} \mathrm{pl}$.] who have received mercy. So it governs and unites us in a single accord. ( $D A 26$ 407:249/408:23 I)

11 Vööbus (I 979) 408:23 I has 'former people', which seems to presuppose a classic replacement theology. Notably, he does not translate nmws' qdmy' as 'former Law'. 
In contrast to the author of the Homilies, who preserves the distinction between Jesus-oriented Jews and Jesus-oriented Gentiles, the Didascalia dissolves the two groups into one, prescribing a common practice for all. Calling his audience 'the elect assembly of God' (DA 9 401:103) the Didascalia seems to embrace a 'remnant theology' reminiscent of that found in some of the books of the prophets and Qumran texts, the only difference being that his remnant also includes Jesus-oriented individuals of Gentile origin.

The author of the Didascalia explains the fact that all Jews did not embrace Jesus and accordingly did not join the 'elect assembly of God' as a result of a blindness that God caused to fall upon them and because he "hardened their hearts like that of Pharaoh' ( $D A 26)$, so that they did not understand that Jesus marked a new era in their history. This blindness was imposed on them because of their failure to keep the laws of the second law: 'However, in not one of them did they abide, but they again provoked the Lord to anger. On this account he yet added to them by the second law a blindness worthy of their works...' (DA 26 408: 227). Although harsher, it bears some resemblance to the theory of concealment in the Homilies and is completely in line with what the biblical prophets accuse Israel of - indeed the author appeals to Isaiah to prove his point of Israel's blindness. ${ }^{12}$

Because of the failure of non-Jesus-believing Jews to recognize Jesus as Israel's Messiah, 'all the activity of the Lord our God has passed from the people to the congregation through us the apostles' (šly $\left.h^{\prime}\right)$ ( $D A 23$ 408:209), a statement that appears to be in line with a classic remnant theology as we know it from the Hebrew Bible and Qumran literature. Even the continuation of the passage, according to which God has 'abandoned the people of the Jews and the temple, and has come to the congregation of the peoples' is consistent with the idea of a righteous remnant to whom God's blessings have been transferred. Our instinct to see in the remnant theology position an expression of Christian supersessionism is the consequence of the projection of a later reality onto these texts. At the time the Didascalia was composed it may have been perceived as anti-rabbinic, but hardly un-Jewish or anti-Jewish.

Entrance into the elect 'assembly of God' is achieved through immersion ( $\left.m^{\prime} m w d y t^{\prime}\right)$, perceived as an initiation rite through which (Jesus-oriented) Jews and Gentiles alike are 'set free from idolatry, and from the second law' ( $D A$ 26 408:228). Through immersion the Jew who has turned to Jesus is absolved of his/her sin of idolatry (= lack of trust in God) - for which the second law 
was imposed - and released from the obligation to keep it. This means that Jews are no longer subject to the laws of purity, rendering purification from menstrual and other impurities unnecessary. The Gentiles, for their part, are cleansed of their idolatrous practices and generally sinful nature, making it possible for them to become part of the people of God: 'But these things he [Christ] endured for our sake, that he might redeem us, those who are of the people from the bonds of the second law ... and that he might redeem you also, who are of the Gentiles, from the fear of idols and from all iniquity, and make you inherit' ( $D A$ I 9 408:I $72.1 \mathrm{I}-\mathrm{I} 5$ ). For both Jews and Gentiles, immersion in water procures forgiveness of sins ( $D A 25$ 408:22 I; $D A 20408: 183),{ }^{13}$ and being an initiation ceremony representing the beginning of a new life it is to be performed only once ( $D A$ 24 408:2 I 5).

In sum, the Didascalia portrays Jesus as a lawgiver with the authority to renew and fulfill the Law by reinstating its original form. In his new saving act God also includes Gentiles, who along with Jesus-oriented Jews are to observe the first Law (but that law only), understood with Jesus as the hermeneutic key. Thus, the distinction between Jew and Gentile gives way to a common identity of the Jesus-adherents who make up 'the congregation of God', the present-day embodiment of the people of Israel.

\section{Gentiles, prophecy and baptism within a Jewish context}

Belief in prophecy and the Messiah, concern with Gentiles and the practice of immersion for the forgiveness of sins are all features of first-century Judaism which have roots in the Bible. One of the reasons we tend to regard them as Christian (i.e. non-Jewish) is that they did not live on in rabbinic Judaism, the form of Judaism that eventually became the sole criterion for determining Jewishness. Another reason is that we automatically assume that what is Christian cannot also be Jewish. Such a separation between Judaism and Christianity did eventually take place of course, but the recent scholarly insight that the parting of the ways was a very slow and messy process, in which adherence to Jesus did not demarcate a major dividing line, makes it unlikely that these developments of first-century phenomena in the third and fourth centuries were regarded, even by rabbinic Jews, as having no relation to Judaism.

13 'But again, sins are forgiven by baptism also to those who from the gentiles draw near and enter the holy congregation of God' ( $D A 20$ 408:183). 
The concern with Gentiles appears to have been a prominent feature of firstcentury Judaism, shared by Jesus-oriented Jews but not unique to them. ${ }^{14}$ It originated much earlier, however and goes back to the time when the Israelites began to see their God as the God of the whole world. 'For all the earth is mine', is the reason God gives for choosing Israel as his special people in Exod. 19:5, a clear indication that the author of this passage believed that in entering into a special relationship with Israel, God also had the other nations in mind. The fate of these nations at the end of time is an issue that occupies the biblical prophets, who foresee that 'all the nations' will come to 'the House of the God of Jacob' in Jerusalem 'in the days to come'(Isa. 2:2-3). Eschatological expectations of the late first century, along with the fact that many Gentiles joined the Jesus movement, must have appeared to the Jesus-adherents as the fulfillment of such prophecies.

Thus, the fact that the communities behind the Homilies and Didascalia (assuming there were communities) included Gentiles does not mean that these authors and communities could not have claimed a Jewish self-identity. The identity of the non-Jewish members of the Jesus movement in the first century seems to have been largely defined by their self-understanding as participants in Judaism and the Jewish communal way of life that applied even to the non-Jewish members (Nanos 20I I: 67), and in light of the outbursts by the Church Fathers over Christian participation in Jewish festivals and synagogue services, some affiliation with Judaism seems to have continued for several centuries, at least in some places. Many Gentiles who joined the Jesus movement seem previously to have adopted Jewish customs and Torah observance (Kimelman 1999, Murray 2004), and it does not seem far-fetched to assume that a Jewish identity persevered for several centuries, not only in groups of purely Jesus-oriented Jews, but also in Jesus-oriented groups made up of both Jews and Gentiles. Although the view of Jewish identity and vision of Judaism in Jesus-oriented groups differed from the rabbinic one, they nevertheless have deep roots in the Hebrew Bible and we should be careful not to dismiss them as un-Jewish by using rabbinic Judaism as the sole criterion of Jewishness.

The first-century practice of immersion to procure the forgiveness of sins is developed in slightly different ways in our three texts. The author of Recognitions I.27-7 I regards it as having replaced the sacrifices in a post-Temple era and presumably sees it as a practice of atonement for individual Jews. In his view,

14 Similar expressions of a universalistic trend are found within rabbinic Judaism in the R. Ishmael school in tannaitic literature (Hirshman 2000: IOI-I 5). 
immersion also seems to function as an initiation rite of sorts, marking adherence to Jesus:

Then he [James] instructed the people, demonstrating that unless one wash in the name of the glorious Trinity in the waters whose flow is living, just as the prophet of truth showed, there will be no forgiveness of sins for him and he will also not enter into the kingdom of God. (Recognitions r.69.5)

The idea that adherence to Jesus, of which immersion 'in the name of the glorious Trinity' is the mark is a necessary prerequisite for entering the kingdom of God (I.69.9, cf. John 3:5) is consistent with the 'remnant theology' of Recognitions I.27-71, according to which belief in Jesus is true Judaism.

The author of the Homilies seems to perceive immersion both as an initiation rite for Gentiles whereby they are cleansed from the general sinfulness inherent in all pagans due to their worship of idols, and as a regular ritual ablution for the purification of the body after defilement ( I I.27-30). Possibly, this is a continuation and development of a first-century ideology according to which notions of ritual and moral impurity had become blurred and immersion was practised as a means of purification from both. According to Jonathan Klawans ( 1997: I 44-69), impurity and sin had merged in the Qumran community, leading to the identification of purification and atonement. Accordingly, immersion (tbykh) was a means of purification from both ritual and moral impurity, and the two were intertwined so that repentance was seen as necessary for the cleansing from ritual impurity to take effect, and likewise atonement was considered incomplete without purification.

Similar ideas are found in the Homilies where purity of body and soul are dependent on each other and where immersion as a means of purification from ritual impurity continues to be practised (I I.28-30,33). After having undergone the initiation rite of immersion for the remission of sins (baptism) Gentile Jesusbelievers are subject to the laws of purity just like Jews (7.8).

According to the author of the Didascalia, both Jesus-believing Jews and Gentiles should undergo immersion for the forgiveness of sins, and for both categories it is a one-time initiation rite marking the beginning of a new life. He argues vehemently against female members of his community who continue to practice ritual purity and immerse after menses $\left(D A_{2} 6\right)$. In contrast to the author of the Homilies, who insists on the importance of both ritual and moral purity, the Didascalia takes a step further abolishing the need for ritual purification altogether, since these laws are part of the second law abolished by Jesus. 


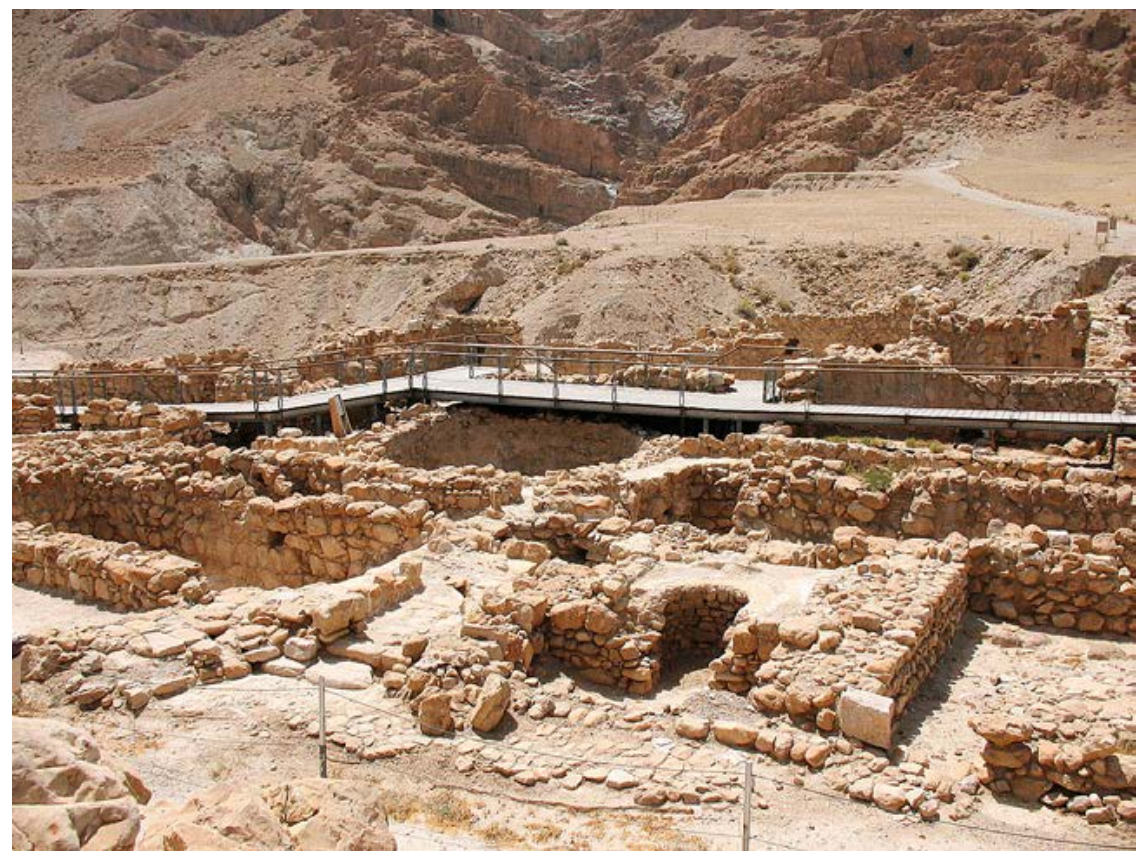

Excavation of Qumran commnity, Dead Sea. Photo by James Emery, 2007. CC-BY-2.0. Wikimedia Commons.

The idea of Jesus as the Messiah, and above all, as a prophet and lawgiver is a continuation of the eschatological- and prophecy-oriented Judaism of the first century that saw Jesus as a prophet with divine authority to teach and interpret the Law. The passage from Deut. I 8: I 5-1 8 that the authors of both Recognitions I.27-7 I and the Homilies refer to in order to assert the divine authority of Jesus through his identification with the future prophet promised by God through Moses, serves the same purpose in the synoptic gospels: 'While he [Peter] was still speaking, suddenly a bright cloud overshadowed them and from the cloud a voice said, "This is my son, the beloved; with him I am well pleased; listen to him!”' (Matt. 3:I 7; cf. Mark I: I ; Luke 3:22).

In spite of the rabbinic insistence that prophecy had ceased from Israel with the last biblical prophets (t. Sot. I 3:3; y. Sot. 9:14; b. Sot. 48b; b. Yoma 9b; b. B. Bat. I 2b; S. Olam Rab. ch. 30), the gospels and Josephus provide evidence that belief in prophecy and prophets continued among first-century Jews (B.J. 2.259-263; A. J. 20.97-98, 20.169-7 I; Matt. I4:5; Mark I I:32; Luke 24: I9; John 4:I9) (Horsley I 985:435-63). In light of this, the rabbinic sources seem to attest more to a desire of the rabbinic movement to establish the authority of its own elite, the rabbis, by claiming that the divine will was now found only in 
the interpretation of the Torah, than to a reflection of reality. It seems likely that some Jews never ceased to believe in prophecy, or perhaps a revival occurred in the first century due to the widespread belief that the end-time was imminent (Sommer i 996: 3 I-47).

Given a number of texts dating from the second to fourth centuries, which combine a strong interest in prophecy with a Jewish, or even priestly self-definition (e.g. Ascension of Isaiah, 5 and 6 Ezra, Testament of the Truelve Patriarchs, Lives of the Prophets, 4 Baruch) and recent claims that the diversity of Second Temple Judaism continued into the early centuries of the common era (Goodman I 994: 347-56; Magness 20 I 2: 69-89; Reed 2006: 323-46) it seems that belief in prophecy was alive and well in non-rabbinic forms of Judaism well into the fourth century. These texts are also oriented towards Jesus is some way, but rather than dismissing them as non-Jewish 'Christian', David Frankfurter (2007) has suggested that they represent forms of prophetic Judaism whose adherents at some point adopted belief in Jesus as the Messiah. In his words: 'Thus, far from seeing a Christian "importation" of Jewish texts, or even a selfconsciously "Christian" appropriation of Jewish traditions, we should posit a multiform "prophetic sectarianism" that continued with a fairly consistent identity and impulse from a Jewish stage into a Jewish and Christ-oriented stage' (ibid. I 39).

If we are ready to at least consider the possibility that belief in prophecy and Jesus continued as orientations within Judaism and that rabbinic Judaism, rather than being the only form of Judaism and the sole criterion for Jewishness, was one group among many others (although admittedly increasingly dominant), a different picture of Judaism during the early centuries of the common era emerges. Given the growing scholarly trend arguing that the rabbinic movement gained in importance and influence only in the third to fourth centuries, or even later (Hezser 1997, Himmelfarb i 993, Schwartz 2001), we ought to consider the possibility that some Jews embraced non-rabbinic forms of Judaism, among them Jesus-orientation.

Although all adherents to the groups I have discussed, combining law observance with belief in Jesus, would not have been considered Jews, even by these groups themselves, the ideas of the mission of the people of Israel envisioned by their authors seem to be part of a thoroughly Jewish worldview. They represent a way of life for Jews and Jesus-oriented non-Jews with the God of Israel at its centre that I, for the lack of a better term, have chosen to call Judaism. Given the ethnic component in the rabbinic view of Jewish identity, leading them to view minim (heretical Jews) as retaining their distinctive identity as Israel in spite of their heretical beliefs and practices (Stern I994: I I-I 2; Alexander 
I 992: 4-6), ${ }^{15}$ I tend to think that provided the authors of these Jesus-oriented texts and a substantial part of their communities were Jews, it is likely that their ideas and ideologies would have been seen as part of Judaism (albeit of the wrong kind) even by rabbinic Jews.

Karin Hedner Zetterholm is a Research Fellow at Lund University and Associate Professor at Linnaeus University. She is the author of Jewish Interpretation of the Bible: Ancient and Contemporary (Fortress Press 2012) and Portrait of a Villain: Laban the Aramean in Rabbinic Literature (Peeters 2002) and of numerous articles on rabbinic Judaism and relations between rabbis and Jesus-oriented Jews, including 'Isaac and Jesus: a rabbinic reappropriation of a "Christian" motif' in Journal of Jewish Studies (forthcoming 2016). Currently, she is involved in a multidisciplinary project on the Jesus movement, early Christianity and rabbinic Judaism.

\section{Bibliography}

Alexander, Philip, I 992. "The parting of the ways" from the perspective of rabbinic Judaism' in Jerws and Christians: The Parting of the Ways A. D. 70 to 135, ed. James D. G. Dunn (Tübingen, Mohr Siebeck), pp. I-25

Boyarin, Daniel, 20 I 2. The Jerwish Gospels: The Story of the Jewish Christ (New York, New Press)

Brenner, Jan N., 20 Io. 'Pseudo-Clementines: texts, dates, places, authors and magic' in The Pseudo-Clementines, ed. Jan N. Brenner (Leuven, Peeters), pp. I-23

Fonrobert, Charlotte Elisheva, 200 r. 'The Didascalia Apostolorum: a mishnah for the disciples of Jesus', Journal of Early Christian Studies, 9(4), pp. 483-509

Frankenberg, Wilhelm, 1937. Die syrischen Clementinen mit griechishem Paralleltext. Eine Vorarbeit zu dem literargeschichtlichen Problem der Sammlung (Leipzig, Hinrichs)

Frankfurter, David, 2007. 'Beyond "Jewish Christianity": continuing religious subcultures of the second and third centuries and their documents' in The Ways That Never Parted: Jerws and Christians in Late Antiquity and the Early Middle Ages, eds Adam H. Becker and Annette Yoshiko Reed (Minneapolis, Fortress Press), pp. I $3 \mathrm{I}-43$

Goodman, Martin, I 994. 'Sadducees and Essenes after 70 CE' in Crossing the Boundaries: Essays in Biblical Interpretation in Honour of Michael D. Goulder, eds Stanley E. Porter et al. (Leiden, Brill), pp. $347-56$

Hezser, Catherine, I 997. The Social Structure of the Rabbinic Movement (Tübingen, Mohr Siebeck)

Himmelfarb, Martha, I 993. 'The parting of the ways reconsidered: diversity in Judaism and Jewish-Christian relations in the Roman Empire: "A Jewish perspective" in Interwoven Destinies: Jews and Christians Through the Ages, ed. Eugene J. Fisher (New York, Paulist Press), pp. 47-6I 
Hirshman, Marc, 2000. 'Rabbinic universalism in the second and third denturies', Harvard Theological Review, 93, pp. IOI-I 5

Horsley, Richard A., I 985. "Like one of the prophets of old": two types of popular prophets at the time of Jesus', Catholic Biblical Quarterly, 47, pp. 435-63

Jones, F. Stanley, I 995. An Ancient Jewish Christian Source on the History of Christianity Pseudo-Clementine Recognitions 1.27-71 (Atlanta, Scholars Press)

-20 I 2. Pseudoclementina Elchasaiticaque inter Judaeochristiana: Collected Studies

(Leuven, Peeters)

Kimelman, Reuven, I 999. 'Identifying Jews and Christians in Roman Syria-Palestine' in Galilee Through the Centuries: Confluence of Cultures, ed. Eric M. Meyers (Winona Lake, Eisenbrauns), pp. 301-33

Klawans, Jonathan, I 997. Impurity and Sin in Ancient Judaism (Ann Arbor, UMI Dissertation Services)

Lieu, Judith M., I 995. 'The race of the God-fearers,' Journal of Theological Studies, 46(2), pp. 483-50 I

Magness, Jodi, 20 1 2. 'Sectarinaism before and after $70 \mathrm{CE}$ ' in Was 70 a Watershed in Jerwish History? On Jews and Judaism before and after the Destruction of the Second Temple, eds Daniel R. Schwartz and Zeev Weiss (Leiden, Brill), pp. 69-89

Marcus, Joel, 2010. 'The testaments of the twelve patriarchs and the Didascalia Apostolorum: a common Jewish Christian milieu?', The Journal of Theological Studies, 6I(2), pp. 596-626

Murray, Michele, 2004. Playing a Jerwish Game: Gentile Christian Judaizing in the First and Second Centuries (Waterloo, Wilfrid Laurier University Press)

Nanos, Mark D., 2o r r. 'Paul and the Jewish tradition: the ideology of the Shema' in Celebrating Paul: Festschrift in Honor of Jerome Murphy-O'Connor, O.P., and Joseph A. Fitzmeyer, S.J., ed. Peter Spitaler (Washinton, DC, Catholic Biblical Association of America), pp. 62-80

_-2014. 'Paul's non-Jews do not become "Jews," but do they become "Jewish"? Reading Romans 2:25-29 within Judaism, alongside Josephus', Journal of The Jesus Movement in Its Jewish Setting, I ( I), pp. 26-52

Reed, Annette Yoshiko, 2006. 'Rabbis, "Jewish Christians," and other late antique Jews: reflections on the fate of Judaism(s) after 70 C.E.' in The Changing Face of Judaism, Christianity, and Other Greco-Roman Religions in Antiquity, eds Ian H. Henderson and Gerbern S. Oegma (München, Gütersloher Verlagshaus), pp. 323-46

2007. "Jewish Christianity" after the "parting of the ways" approaches to historiography and self-definition in the Pseudo-Clementines' in The Ways That Never Parted: Jews and Christians in Late Antiquity and the Early Middle Ages, eds Adam H. Becker and Annette Yoshiko Reed (Minneapolis, Fortress), pp. I 89-23 I

2008. “Jewish Christianity” as counter-history? The apostolic past in Eusebius' Ecclesiastical History and the Pseudo-Clementine Homilies' in Antiquity in 
Antiquity: Jewish and Christian Pasts in the Greco-Roman World, eds Gregg Gardner and Kevin L. Osterloh (Tübingen, Mohr Siebeck), pp. I 72-2 I 6 -2013. 'When did rabbis become Pharisees? Reflections on Christian evidence for post-7o Judaism' in Envisioning Judaism: Studies in Honor of Peter Schäfer on the Occasion of his Seventieth Birthday, eds Ra'anan S. Boustan et al. (Tübingen, Mohr Siebeck), pp. 860-95

Rehm, Bernhard r 953. Die Pseudoklementinen, vol. r: Homilien (Berlin, Akademie Verlag)

— I965. Die Pseudoklementinen, vol. 2: Rekognitionen in Rufinus Übersetzung (Berlin, Akademie Verlag)

Reynolds, Joyce, and Robert Tannenbaum, I 987. Jerws and Godfearers at Aphrodisias: Greek Inscriptions with Commentary (Cambridge Philological Society)

Roberts, Alexander, and James Donaldson, I 870. The Clementine Homilies and the Apostolic Constitutions (Edinburgh, T\&T Clark)

Schwartz, Seth, 200 I. Imperialism and Jewish Society, 200 B.C.E to 640 C.E. (Princeton University Press)

Sommer, Benjamin, I 996. 'Did prophecy cease? Evaluating a reevaluation', Journal of Biblical Literature, I I 5(I), pp. 3 I-47

Stern, Sacha, I 994. Jewish Identity in Early Rabbinic Writings (Leiden, Brill)

Stewart-Sykes, Alistair, 2009. The Didascalia Apostolorum: An English Version with Introduction and Annotation (Turnhout, Brepols)

Vööbus, Arthur, r 979. The Didascalia Apostolorum in Syriac, 4 vols. (Louvain, Corpus Scriptorum Christianorum Orientalium)

Yadin-Israel, Azzan, 201 3. 'Qabbalah, Deuterosis, and semantic incommensurability' in Envisioning Judaism: Studies in Honor of Peter Schäfer on the Occasion of his Seventieth Birthday, eds Raanan S. Boustan et al. (Tübingen, Mohr Siebeck), pp. 9I 7-39

Zellentin, Holger Michael, 20 13. The Qur'an's Legal Culture: The Didascalia Apostolorum as a Point of Departure (Tübingen Mohr Siebeck) 